Kapidani, M., \& Luci, E. (2019). The Effects on Innovation from Financial Sector Development: Evidence from Developing Countries. Journal of Competitiveness, 11(2), 84-94. https://doi.org/10.7441/ joc. 2019.02 .06

\title{
THE EFFECTS ON INNOVATION FROM FINANCIAL SECTOR DEVELOPMENT: EVIDENCE FROM DEVELOPING COUNTRIES
}

\section{- Mariola Kapidani, Edlira Luci}

\begin{abstract}
The subject of financial system development is widely studied in the finance literature as an indicator of economic growth and a driver of technological innovation supporting the mobilization of capital for growth. However, varying results are obtained when examining developed countries compared to the emerging countries. Developing countries are characterized by a lower investment in innovation, and lower levels of competitiveness in terms of research and development funding, fewer research academic institutions, but also lower incentives for private innovation by enterprises. The purpose of this paper is to examine the relationship between financial development indicators and innovation by analyzing data for 15 developing countries within the time frame of 1996-2016. The financial system is analyzed in two main pillars: credit institutions and equity markets. The number of innovation patent applications is the dependent variable of the study, i.e. as an indicator of a country's innovative performance. The results of the study show that a higher level of crediting by the banking sector will positively affect the number of patent applications. Credit mobilization by other financial intermediaries in the financial system such as equity markets or non-banking institutions show a lower efficiency in boosting innovation activities, resulting in the opposite effects regarding the number of patent applications. Countries with a higher level of education will show more efforts toward innovation and the development of innovative practices. On the other hand, higher competitiveness among companies in terms of technology innovation and processes is expected to boost the demand for funds in the financial system, leading to the improvement in system development.
\end{abstract}

Keywords: financial development, innovation, financial system, patent application, competitiveness JEL Classification: G15, O30, R11

Received: November, 2018

1st Revision: April, 2019

Accepted: April, 2019

\section{INTRODUCTION}

The development of the financial system and its instruments is becoming increasingly important in the literature as an indicator of economic growth, foreign investment attraction, poverty reduction and the overall development of the country's economy. Several studies on economic growth factors have identified a positive relationship between economic growth and the devel- 
opment of the financial system, taking into account indicators such as the expansion of financial services and financial intermediation. Evidence indicates that the presence of a healthy and balanced system of financial services stimulates the increase of output (Beck \& Levine, 2002). On the other hand, financial stability directly affects the progress of macroeconomic stability. Nevertheless, a complex relationship between the financial sector expansion and its effect on economic growth can be identified, one which takes into account evidence from several financial crises and their impact on the economy. Levine (2005) concludes that financial development positively affects resource allocation. This result derives from the argument that productivity and economic growth are achieved by creating innovative processes that boost investment and, therefore, growth.

Although there is a vast literature including academic research which examines the nexus of financial development - economic growth, only a few studies empirically examine the specific means by which the financial sector affects growth. Innovation and the upgrade of production processes influence economic growth to a large extent; this is a broadly accepted argument in the literature supporting the role that healthy financial markets play in this process by enabling investment flow and boosting competitiveness in technological innovation (King \& Levine, 1993). A challenge for the studies in the field of innovation, growth and financial development is the empirical representation of innovation variables. Several studies use the patent count of a country to analyze its innovation activity (Conti et al., 2013; Hottenrott et al., 2016). Other studies examine R\&D allocations along with legal incentives such as patent protection and patent rights (Maskus et al., 2019). Holmstrom (1989) points out that the dissimilar nature of credit and equity markets each have a different impact on encouraging innovation, taking into account the unpredictable nature of innovation process and the difficulties of forecasting degrees of success or possibilities of failure. Another aspect of the empirical analysis is that different results are obtained when examining developed countries as compared to emerging countries (Dabla Norris et al., 2012).

Considering these contradictory results in different country groups, we have focused the analysis on the developing countries and the main factors that are relevant in emerging economies. The main objective of the paper is to provide cross-country evidence to empirically examine how financial developments affect innovation, as a channel of economic growth. The variables used in the analysis represent indicators of crediting institutions and non-banking institutions of the financial sector. The literature review shows that for the developing countries, credit market development and stock market development affect innovation to a different degree. For this reason, the nexus innovation-financial development is firstly examined for the financial sector as a whole, and a second model is assessed for the equity market in particular. Innovation is included in the model using the macroeconomic approach, choosing as independent variable the number of innovation patent applications. In the first part of the paper we will provide the literature review on the subject, main instruments and variables that result relevant from the literature and the empirical conclusions of previous studies. The methodological approach and variable's explanation is examined further in the third section of the paper. The last section of the study concludes with discussions, results and recommendations for the future on the topic of finance and innovation. 


\section{THEORETICAL FRAMEWORK}

In a 19th century study relevant to the subject, Bagehot (1873) argued that in the first stages of industrialization in England, the financial system highly affected the process and growth outcomes by supporting the transfer of resources and mobilization of capital. Later, Schumpeter (1934) claimed that innovation in the use of existing resources might boost economic growth. He stated that financial intermediaries can play a significant role in the degree of innovation employed, i.e. considering that well-adjusted banks guarantee a process of identifying profitable business plans in innovation along with facilitating the development of new markets and processes. The internationalization of economies and businesses requires the permanent innovation of processes and practices in order to acquire competitive advantages and to effectively compete during new market developments (Callegari, 2018). According to Porter (1992), this innovation is achieved from investment in physical as well as intangible assets. From a classical perspective, Schumpeter (1911) believed that the financial system is important for contributing to innovation, which in turn positively influences economic growth. Nevertheless, the neo-Schumpeterian line of research has marginalized these theoretical findings in favor of an empirical assessment focused primarily on technological aspects of innovation (Callegari, 2018). On the other hand, higher competitiveness between companies in terms of technology innovation and process developments is assumed to boost the demand for funds in the financial system, leading to the improvement of financial system development.

Along the same lines, modern day theories suggest that the development of the financial system aids innovation processes by providing financial services such as risk management and information facilitation, which in turn leads to lowering transaction costs. These services as a result support investment in innovation in risky business projects but with a long-run profitable potential (Levine, 1997; Gries et al., 2011). However, historically opposing views have emerged concerning whether financial development in fact does influence economic growth. Robinson (1952), as an example, supported the opposite view, i.e. that financial development comes from economic growth. Meanwhile, a consensus has emerged in the finance and economics literature that, in general, innovation is a positive influence on economic growth (Sharma, 2007; Kingston, 2014). Studies assessing data for highly developed economies conclude that economic growth objectives are reached by having access to global innovation networks, i.e. developing technologies through capital accumulation from financial channels as well as insuring access to domestic and foreign networks of trade and institutional cooperation with research centers and universities (Moguillansky, 2006). Therefore, the relationship between financial development and innovation indicators is projected to be positive. Meanwhile, developing countries are characterized by a lower government investment in innovation in terms of research and development funding, the presence of fewer research academic institutions, but also on the other hand by lower competitiveness for private innovation by enterprises (Aristizabal-Ramirez et al., 2017). Hence, when studying the effect of financial development on innovation for the developing economies, the disparities in the results in comparison with developed countries may be explained by the narrow size of the financial sector along with the other factors mentioned in this paragraph.

De la Fuente \& Marin (1996) conclude that financial intermediation is important for lowering informational difficulties and financing risky innovative activities; i.e. economic growth is posi- 
tively influenced by financing innovation. Rajan \& Zingales (1998) put forth another argument, i.e. that in the countries with a better developed financial system, more young companies start up, thus increasing the effect of finance on innovation. Economic growth is thus enhanced for countries in which financial intermediation supports the development of innovative companies and sectors (Allen et al., 2018; Igan et al., 2016). Tadesse (2005) finds that innovation is an important channel through which finance influences growth, given that innovations and the lowering of production costs enhance productivity. Tadesse concludes in his thesis that the financial sector has a strong positive influence on technological progress, and thus on competitiveness on creating innovation. According to his study, for the countries with a better developed banking sector, the effect of innovation in productivity gain is significant. This result is also relevant for the countries with larger stock markets (Chava et al., 2017). One approach to study the influence of the financial sector on innovation is on the micro level and the other approach studies the macroeconomic level (Conti et al, 2013). Kim \&Lee (2007) take a macroeconomic approach, using as a measure of innovation the number of patents registered. It is observed that patent growth is positively influenced by a better developed financial sector (Fischer et al., 2014), for the developing countries studied. From these studies, it can be concluded, on a micro as well as a macro level, that finance is of positive influence on innovation (Hottenrott et al., 2016). It is yet important to study further the effects of capital markets and the credit market on innovation support, and examine if the growth objectives are reached (Hsu et al., 2014).

\section{RESEARCH OBJECTIVES AND METHODOLOGY}

In this paper, we have firstly introduced a number of concepts that are important for the financial sector development analysis and its impact on economy. Secondly, we have reviewed the literature on innovation as a significant channel of economic growth in the macro level approach. Lastly, we have analyzed the link between financial system development and its effect on innovation taking into account the developing countries. A common characteristic of these countries is that financial sector is more limited to the banking sector and the innovation practices are less supported compared to developed economies. The basic hypothesis of the paper is that the credit market and equity market development have different impacts on innovation. The effect of financial development variables on innovation will be explained by the OLS model, including control variables such as indicators of financial development and financial deepening, the level of education and economic growth. We aim to contribute to the current literature on the importance of financial intermediaries in supporting innovation, and the degree of impact of each explanatory variable in the model. The paper has also the objective to provide alternative indicators in measuring and explaining financial system development, specifically for the right approach toward developing countries.

To analyze the link between financial development and its impact on innovation, the panel data for 15 developing countries is assessed for the time frame of 1996-2016. The analyzed countries in the model are: Argentina, Bulgaria, Georgia, Indonesia, Jordan, Malaysia, Mexico, Peru, Philippines, Romania, Russian Federation, South Africa, Thailand, Turkey, and Ukraine. The principle for the selection of these specific 15 countries is to have a representation of broad regions in the world. Another factor of defining the selection of countries is related to availability of data 
for the variables of the study for the period 1996-2016. The total number of observations for the panel data is 315 . The first hypothesis tested for the study is: the financial system development positively effects innovation. The second hypothesis of the study is: capital markets development and banking sector development demonstrate a different degree of effect on innovation. These two main research questions are to be examined in the paper and discussed, with the aim of formulating important conclusions. The finding of the study aims to address the harmonization between development of innovation processes and products in the private sector and the necessary institutional framework improvement for better resource allocation and effective funding by the financial system.

The regressive model OLS for the panel data is based on the previous literature and the indicators considered important for the link. The patent count data is used as the dependent variable, as an indicator of innovation activity of the country. This approach is considered important because the patent count enables information on innovative performance of a country in terms of new technologies, new products and new processes (Conti et al., 2013; Hottenrott et al., 2016). On the other hand, financial development is measured by different indicators and it presents different methodological approaches in the literature. The main suggested explanatory variables for the financial development in the literature are: liquid liabilities to GPD, private credit to GDP and stock market capitalization to GDP. However, other control variables are considered for the analysis. Education is expected to play an important role in the level of innovation, so education indicators should be included in the analysis. Education is widely represented by the variable of students' enrollment in secondary education. To measure the differentiated effect of equity markets and capital markets, banking sector specifics and stock exchange indicators are assessed separately. The interval of time for the study is dependent on the consistency of data for the chosen countries, which makes a limitation for the study.

Tab. 1 - Description of the dependent and independent variables. Source: own research

\begin{tabular}{|l|l|}
\hline Dependent & Notation \\
\hline The number of innovation patent applications (in logarithmic form) & PA \\
\hline Independent & GDP \\
\hline GDP per capita, PPP (in logarithmic form) & SMC \\
\hline Stock market capitalization to GDP (in logarithmic form) & BC \\
\hline Bank credit to bank deposits (in logarithmic form) & DMB \\
\hline Deposit money bank assets to GDP (in logarithmic form) & PCT \\
\hline $\begin{array}{l}\text { Private credit by deposit money banks and other financial institutions to GDP } \\
\text { in logithmic form) }\end{array}$ & SMV \\
\hline Total value of shares traded to GDP (stock market) (in logarithmic form) & ED \\
\hline Gross student enrolment rate, secondary education (in percentage) & LL \\
\hline Liquid Liabilities to GDP (in logarithmic form) & \\
\hline
\end{tabular}

The regression is formulated on the Ordinary Least Square for the Panel Data method, testing the random or fixed effects of the model for the specification of final regression. To ensure the 
reliability of the proposed econometric model, the given tests are applied to support the assumptions of the regression: test of normality of residuals; test of homoscedasticity of residuals; test of multicollinearity; test of autocorrelation; and test of linearity. The Wald test and Housman test are also applied to the regression to specify the panel data effects. The limitations of the study rely on the availability of financial information and the patent application count for developing economies. A second limitation is the interval of study from 1996 to 2016, which might expose consistent changes in legislation framework of the patent registration as well as many trend instabilities in the financial indicators, pertaining to external factors that are not considered in the study. The third limitation of the study is the number of countries, consisting of 15 developing countries. A larger number of countries composing the studied sample could improve the reliability of the regression results, thus providing stronger empirical data from regions around the world. Nevertheless, the chosen empirical method was adapted to fit the limitations of the study and to make the necessary corrections for the model.

\section{RESULTS AND DISCUSSION}

Our first analysis tested the significance of financial system development on innovation for the 15 developing countries included in the model in a time interval of 21 years. Drivers of financial sector development are represented in the study by these indicators: liquid liabilities to GDP, bank credit to bank deposit, total value of shares traded to GDP, private credit by domestic money banks and other financial institutions to GDP, along with deposit money bank assets to GDP. Education is included in the analysis through the indicator gross student enrolment rate in secondary education. The source for the gathered data is the World Bank database (development indicators and the global financial development database). The dependent variable of the model is the number of patent innovation applications, with data taken from the world intellectual property organization (WIPO).

$P A=C+\beta 1 * L L+\beta 2 * B C+\beta 3^{*} S M V+\beta 4^{*} E D+\beta 5^{*} P C T+\beta 6^{*} D M B$

After testing for cointegration, the model is further tested for the significance of independent variable as presented in Table 2 . The OLS regression for the panel data shows that: bank credit to bank deposit, total value of shares traded to GDP, as well as deposit money bank assets to GDP have a significant positive relation to the innovation indicator. This result underlines the importance of financial sector development to the number of innovation patent applications. Meanwhile, the liquid liabilities to GDP and the private credit by domestic money banks and other financial institutions to GDP indicators show a significant negative relation with the innovation indicator. When the financial system is assessed in the model, including both crediting institutions and equity market indicators, the results show that for the developing countries the level of crediting in economy by the financial system as a whole does not have a positive effect on the number of patent applications. As noted in the theoretical review of the study, this can be explained by the finding that in the case of developing countries, capital flows are not efficiently directed toward innovation practices and products. Innovation practices are often perceived as risky and do not find strong or even adequate support from the financial institutions, as included in the model as a total of crediting from banking and non-banking intermediaries. The financial 
sector in developing countries is not balanced in terms of banking sector development compared to non-banking institutions. As a result, we expected a significant positive relation of the banking sector development indicators (BC, DMB), as a common characteristic the banking sector in developing countries is its role as the main intermediary of the financial system. As expected, the education indicator (gross student enrolment rate in secondary education) has a positive significant relation to the innovation indicator. Countries with a higher level of education will show results in terms of more efforts toward innovation and the development of innovative practices in the private and public sector.

Tab. 2- Test results for effect of financial sector indicators on innovation. Source: own research of the authors

Dependent Variable: PA

Method: Panel Least Squares

Periods included: 21

Cross-sections included: 15

Total panel observations: 315

\begin{tabular}{|l|l|l|l|l|}
\hline Variable & Coefficient & Std. Error & t-Statistic & Prob. \\
\hline LL & -1.716636 & 0.321286 & -5.343007 & 0.0004 \\
\hline BC & 1.323022 & 0.174483 & 7.582528 & 0.0001 \\
\hline SMV & 0.233271 & 0.051712 & 4.510933 & 0.0023 \\
\hline ED & 0.034739 & 0.006229 & 5.576943 & 0.0000 \\
\hline PCT & -1.493638 & 0.259531 & -5.755151 & 0.0009 \\
\hline DMB & 2.333189 & 0.478266 & 4.878430 & 0.0015 \\
\hline
\end{tabular}

\begin{tabular}{|l|l|l|l|}
\hline R-squared & 0.544581 & Mean dependent var & 6.234450 \\
\hline Adjusted R-squared & 0.432032 & S.D. dependent var & 1.614760 \\
\hline S.E. of regression & 1.415075 & Akaike info criterion & 3.551593 \\
\hline Sum squared resid & 602.7337 & Schwarz criterion & 3.624430 \\
\hline Log likelihood & -539.1695 & Hannan-Quinn criter. & 3.580720 \\
\hline Durbin-Watson stat & 0.160008 & & \\
\hline
\end{tabular}

Taking into consideration the fact that crediting institutions show a different effect on the innovation practices compared to other institutions in the financial sector, the second analysis was conducted for the stock market indicators. The significance of the relation of the equity market development to patent application is tested by the OLS model for the panel data, as shown below. Education and economic growth are also included in the model as the controlling variable. The chosen indicators for stock market development are conditioned by the availability of data for the interval of study in the analyzed countries.

$P A=C+\beta 1 * S M C+\beta 2 * S M V+\beta 3^{*} E D+\beta 4^{*} G D P$ 
Further results are presented in Table 3. The variables of total value of shares traded to GDP, gross student enrolment rate in secondary education along with GDP per capita, show a positive significant relation to the number of patent applications. Meanwhile, stock market capitalization to GDP shows a negative significant relation to the number of patent applications for the developing countries. Regarding the stock market, we can also conclude from the study that a higher activity in market trade will result in more funds toward innovation activities. However, the stock market capitalization indicator shows that the equity markets in developing countries are not efficient in channeling capital toward innovation. Education still presents a positive effect on the number of patent applications. In addition, the GPD per capita indicator shows a positive significant relation to innovation, a finding which might be explained by the assertion that the higher economic development of a country would require greater efforts toward innovative technologies and processes.

Tab. 3 - Test results for the second analysis, equity market effects on innovation. Source: own research of the authors.

\begin{tabular}{|c|c|c|c|c|}
\hline \multicolumn{5}{|c|}{ Dependent Variable: PA } \\
\hline \multicolumn{5}{|c|}{ Method: Panel Least Squares } \\
\hline \multicolumn{5}{|c|}{ Periods included: 21} \\
\hline \multicolumn{5}{|c|}{ Cross-sections included: 15} \\
\hline \multicolumn{5}{|c|}{ Total panel observations: 315} \\
\hline Variable & Coefficient & Std. Error & $\mathrm{t}$-Statistic & Prob. \\
\hline SMC & -0.492379 & 0.098811 & -4.983056 & 0.0000 \\
\hline SMV & 0.273914 & 0.068992 & 3.970222 & 0.0001 \\
\hline ED & 0.023550 & 0.007215 & 3.264026 & 0.0012 \\
\hline GDP & 0.596172 & 0.072742 & 8.195756 & 0.0000 \\
\hline
\end{tabular}

\begin{tabular}{|l|l|l|l|}
\hline R-squared & 0.507155 & Mean dependent var & 6.234450 \\
\hline Adjusted R-squared & 0.399305 & S.D. dependent var & 1.614760 \\
\hline S.E. of regression & 1.444912 & Akaike info criterion & 3.586918 \\
\hline Sum squared resid & 632.5947 & Schwarz criterion & 3.635476 \\
\hline Log likelihood & -546.5919 & Hannan-Quinn criter. & 3.606336 \\
\hline Durbin-Watson stat & 0.145590 & & \\
\hline
\end{tabular}

The results of our study suggest a different attitude to capital flows when each separate channel of the financial system is assessed. Considering the consequences of these types of studies, further incentives must be undertaken in order to direct capital flows toward productivity and cost effective innovation projects. Moral hazards and information asymmetry might restrain the crediting of new enterprises and innovation products or practices, which is an argument reflected mostly in the capital markets, especially for developing countries, where financial information disclosure is less consistent. Incentives for higher information disclosure and copyright protection leads to a decrease in information asymmetry and higher reliability of startup innovative 
companies for funding. Greater attention should be directed towards institutional framework improvement in patent applications to ensure the validity of these findings, as well as to create stronger links between the research world (whether conducted in private companies or public institutions) and the crediting system. In terms of financial market share, in cases where capital markets and banking institutions lack interest in innovation projects, semi-formal channels in the financial system could play a stronger role in the provision of financial assistance. Institutions such as microfinance mechanisms could facilitate the financing process to companies that are less established in the market, with a special focus on innovation. Widening the scope of financial services within the financial system could help resolve problems in innovation crediting, as well as encourage flows of public savings toward less traditional forms of funding.

\section{CONCLUSIONS}

The main objective of this paper is to provide cross-country evidence for an empirical examination of how financial development as a channel of economic growth effects innovation. The panel data for 15 developing countries is examined for the period 1996-2016. The nexus of innovation-financial development is firstly analyzed for the financial sector as a whole, following which a second model is assessed specifically for the equity market. Our results suggest that banking sector development has a significant relation to innovation activities as represented by the number of patent applications. In developing countries, the financial sector consists mostly of bank institutions. For this reason, different results are expected regarding how banking institutions and non-banking institutions affect the innovation indicator. A more developed financial system provides firms with a better access to financing innovation as well as technological advances. In our model, however, it is evident that the crediting in the economy, i.e. when banking and non-banking institutions (including the equity market) are analyzed as a whole, lacks the efficiency to direct capital flows towards innovation practices, resulting in a negative effect in the amount of patent applications. The GPD per capita indicator shows a positive significant relation to innovation, a finding which might be explained by the assertion that the higher economic development of a country would require more efforts in innovative technologies and processes. Also, a higher education level will affect the number of patent applications, a finding which demonstrates a closer relationship between knowledge and innovation practices. As is shown in the study, a lack of effectiveness in the financial sector in terms of financing innovation should be addressed by strengthening the institutional framework in patent and copyright protection, as well as by widening the scope of financial instruments and services by incorporating alternative institutions such as microfinance mechanisms. Considering finance-innovation as a complete interconnected system could provide better results in terms of financing, productivity and risk management by solving issues concerning the moral hazards and information asymmetry faced in this relation. Thus, higher information disclosure and higher attention to innovation, along with strengthening the cooperation between academia, the private sector and the financial system, could lead to more effective innovation financing. 


\section{References}

1. Allen, F., Gu, X., \& Kowalewski, O. (2018). Financial structure, economic growth and development. In: Beck, Thorsten, Levine, Ross (Eds.), Handbook of Finance and Development. Edward Elgar Publishing, Inc, Cheltenham, UK and Northampton, MA, USA, 31-62.

2. Aristizabal-Ramirez, M., Botero-Franco, M. C., \& Canavire-Bacarreza, G. J. (2017). Does Financial Development Promote Innovation in Developing Economies? An Empirical Analysis. Review of Development Economics, 21 (3), 475-496.

3. Bagehot, W. (1873). Lombard Street: A Description of the Money Market. Reprinted (1962). Homewood, IL, Irwin, R.D.

4. Beck, T., \& Levine, R. (2002). Industry Growth and Capital Allocation: Does Having a Market or Bank-Based System Matter? Journal of Financial Economics, 64 (2), 147-180.

5. Beniamino, C. (2018). The finance/innovation nexus in Schumpeterian analysis: theory and application to the case of U.S. trustified capitalism. Journal of Evolutionary Economics, 28, 1175-1198.

6. Chava, S., Nanda, V., \& Xiao, S. Ch. (2017). Lending to innovative firms. The Review of Corporate Finance Studies, 6 (2), 234-289.

7. Conti, A., Thursby, J., \& Thursby, M. C. (2013). Patents as signals for startup financing. The Journal of Industrial Economics, 61 (3), 592-622.

8. Dabla-Norris, E., Kersting, E. K., \& Verdier, G. (2012). Firm Productivity, Innovation, and Financial Development. Southern Economic Journal, 79 (2), 422-449.

9. De La Fuente, A., \& Marin, J. (1996). Innovation, bank monitoring, and endogenous financial development. Journal of Monetary Economics, 38, 269-301.

10. Fischer, T., \& Ringler, P. (2014). What patents are used as collateral? An empirical analysis of patent reassignment data. Journal of Business Venturing, 29 (5), 633-650.

11. Gries, Th., Manfred, K., \& Daniel, M. (2011). Financial deepening, trade openness and economic growth in Latin America and the Caribbean. Applied Economics, 43, 4729-4739.

12. Holmstrom, B. (1989). Agency costs and innovation. Journal of Economic Behavior and Organization, 12, 305-327.

13. Hottenrott, H., Hall, B. H., \& Czarnitzki, D. (2016). Patents as quality signals? The implications for financing constraints on R\&D. Economics of Innovation and New Technology, 25 (3), 197-217.

14. Hsu, P. H., Tian, X., \& Xu, Y. (2014). Financial Development and Innovation: CrossCountry Evidence. Journal of Financial Economics, 112 (1), 116-135.

15. Igan, D., Kutan, A. M., \& Mirzae, A. (2016). Real Effects of Capital Inflows in Emerging Markets. International Monetary Fund Working Paper, no. 16/235.

16. Kim, P., \& Lee, K. (2007). The effect of financial sector development on innovation as an engine of sustained growth. Seoul Journal of Economics, 20 (1).

17. King, R., \& Levine, R. (1993a). Finance, Entrepreneurship and Growth. Journal of Monetary Economics, 32, 513-542. 
18. King, R., \& Levine, R. (1993b). Finance and Growth, Schumpeter Might Be Right. Quarterly Journal of Economics, 108, 717-738.

19. Kingston, W. (2014). Schumpeter and the end of Western capitalism. Journal of Evolutionary Economics, 24, 449-477.

20. Levine, R. (1997). Financial Development and Economic Growth: Views and Agenda. Journal of Economic Literature, 35, 688-726.

21. Levine, R. (2005). Finance and Growth: Theory and evidence, Handbook of Economic Growth, Vol.1a.

22. Maskus, K. E., Milani, S., \& Neumann, R. (2019). The impact of patent protection and financial development on industrial R\&D. Research Policy, 48 (2019), 355-370.

23. Moguillansky, G. (2006). Innovation, the Missing Link in Latin American Countries. Journal of Economic Issues, 40 (2), 343-357.

24. Porter, M. E. (1992). Capital disadvantage: America's Failing Capital Investment System. Harvard Business Review, 70, 65-82.

25. Rajan, R. G., \& Zingales, L. (1998). Financial Dependence and Growth. American Economic Review, 88, 559-586.

26. Robinson, J. (1952). The Rate of Interest and Other Essays. London: Macmillan.

27. Schumpeter, J. (1911). The Theory of Economics Development. Cambridge, MA: Harvard University Press.

28. Schumpeter, J. A. (1934). The theory of economic development: An inquiry into profits, capital, credit, interest, and the business cycle (Vol. 55). Transaction Publishers.

29. Sharma, S. (2007). Financial Development and Innovation in Small Firms. World Bank Policy Research Working Paper Series, 2007.

30. Tadesse, S. (2005). Financial Development and Technology. William Davidson Institute Working Paper, 749.

31. World Bank. (2018). World Bank's Financial Development and Financial Structure Dataset. Available at http://econ.worldbank.org.

\section{Contact information}

\section{MSc. Mariola Kapidani}

University of Tirana, Albania

Faculty of Economics

Department of Finance

Albania

E-mail:mariolakapidani@feut.edu.al

ORCID: 0000-0001-6928-6009
Prof. Assoc. Dr. Edlira Luci

University of Tirana, Albania

Faculty of Economics

Department of Finance

Albania

E-mail:edliraluci@feut.edu.al

ORCID: 0000-0002-6246-6178 